\title{
The effect of small dams in Rawa Pening catchment area on sedimentation rate of Rawa Pening Lake
}

\author{
Dyah Ari Wulandari ${ }^{1, *}$, Dwi Kurniani ${ }^{1}$, Sutarto Edhisono ${ }^{1}$, Ferdian Ardianto $^{1}$, and Denri Dahlan ${ }^{1}$ \\ ${ }^{1}$ Department of Civil Engineering, Faculty of Engineering, Diponegoro University, Semarang, Indonesia
}

\begin{abstract}
Rawa Pening Lake is one of fifteen priority lakes. The problem in Rawa Pening Lake is the rapid sedimentation rate and blooming of water hyacinth which has an impact on the decreasing of storage capacity and water quality. The handling has not shown significant results. Therefore, that it needs to innovate on improvement and maintenance of Rawa Pening Catchment Area that has never done that is in the form of small dam development in Rawa Pening catchment area. The construction of a small dam in the Rawa Pening catchment area can temporarily hold water and prevent the rate of sediment from entering the lake. The purpose of this research is to analyse the influence of small dams in the Rawa Pening catchment area to sedimentation rate in Rawa Pening Lake. Sedimentation is calculated based on soil erosion in the catchment area, using the USLE formula. If There are 40 small-dams in Lake Rawa Pening catchment area, the sedimentation decreased to $78.75 \%$. If there are only 2 small-dams constructed in the Klegung sub-watershed and the Legi sub-watershed, the sedimentation decrease to $67 \%$.
\end{abstract}

\section{Introduction}

Rawa Pening Lake is a natural lake that has role as a natural reservoir used for hydropower, raw water sources, irrigation, fisheries, and tourism. Under the Bali Agreement of 2009, Rawa Pening Lake is one of fifteen priority lakes. The Ministry of Tourism seeks to make
Rawa Pening a tourist attraction as a world tourism destination. Rawa Pening Lake located in Salatiga Regency and Semarang Regency, Central Java Province (Figure 1). The catchment area of Rawa Pening Lake is upstream of the Tuntang watershed. Administratively, the catchment area of Rawa Pening Lake covers 72 villages in 11 sub-districts in Semarang and Salatiga Regencies.

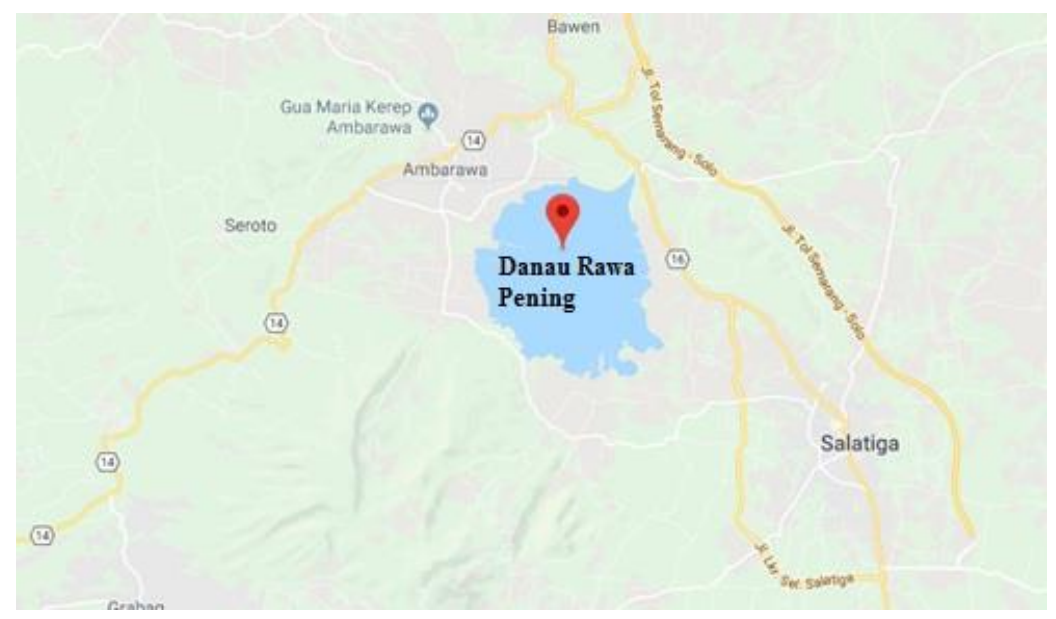

Fig. 1. Research Location (Google Map, 2018)

Hydrologically, the water of Rawa Pening Lake comes from rainfall, groundwater, and surface water from 17 river streams. The catchment area of Rawa Pening Lake covers an area of 25,041.50 Ha. The water release of Rawa Pening Lake through 1 outlet without the controller that is the Tuntang River and this is the cause of flooding in the Grobogan. Rawa Pening Lake water is $80 \%$ wasted into the sea during the rainy season, and only $20 \%$ can be utilized [1].

\footnotetext{
* Corresponding author: dyahariwulandari@yahoo.co.id
} 
According to [2] sediment loads in the tributaries which entering Rawa Pening Lake higher than in the outlet. This indicates that Rawa Pening Lake acts as a shelter of sediment deposition and nutrients from the surrounding rivers. Spatially and temporally the condition of water quality in the lake shows high variation. High nutrient concentrations in the lake during the rainy and dry seasons indicates that the nutrients source not only comes from outside but also from within the lake itself. The results of this study indicate that Rawa Pening Lake is a eutrophic lake. Phosphorus is thought to be the main factor causing eutrophication and growth of water hyacinth. The land functions conversion that occurred in the Rawapening Sub-watershed triggered an increase in erosion rate which resulted in high sedimentation in Rawapening Lake [3].

Tributaries of Rawa Pening Lake carry river mud and various kinds of agricultural, livestock, and industrial wastes from communities around the river flow with nitrogen and phosphorus content. This causes another problem that occurs in Rawa Pening Lake that is water hyacinth blooming. Even in 2011, the water hyacinth weed covered the surface area of the lake approximately 1,080 hectares or about 70 percent of the lake area [1].

Returning of the capacity and function of Rawa Pening Lake was carried out starting in 2016 by the Ministry of PUPR through the Balai Besar Wilayah Sungai Pemali Juana. Measurements were taken covering sedimentation control in the form of dredging and construction of check dams, determination of border zones of the lake, construction of embankments of border zones of the lake, and control of aquatic weeds by routine cleaning of water hyacinth [4].

The planning of Rawa Pening Lake management is developed to determine the potential locations of the small dams which are useful to reduce the peak hydrograph of Tuntang River floods and increase low flows of Rawa Pening Lake [1]. From this research, there are 40 potential locations of small-dams in 16 tributaries entering Rawa Pening Lake (Figure 2). This study proves that the smalldams in the Rawa Pening Watershed can reduce the flood, so the risk of flooding along the Tuntang River can be reduced.

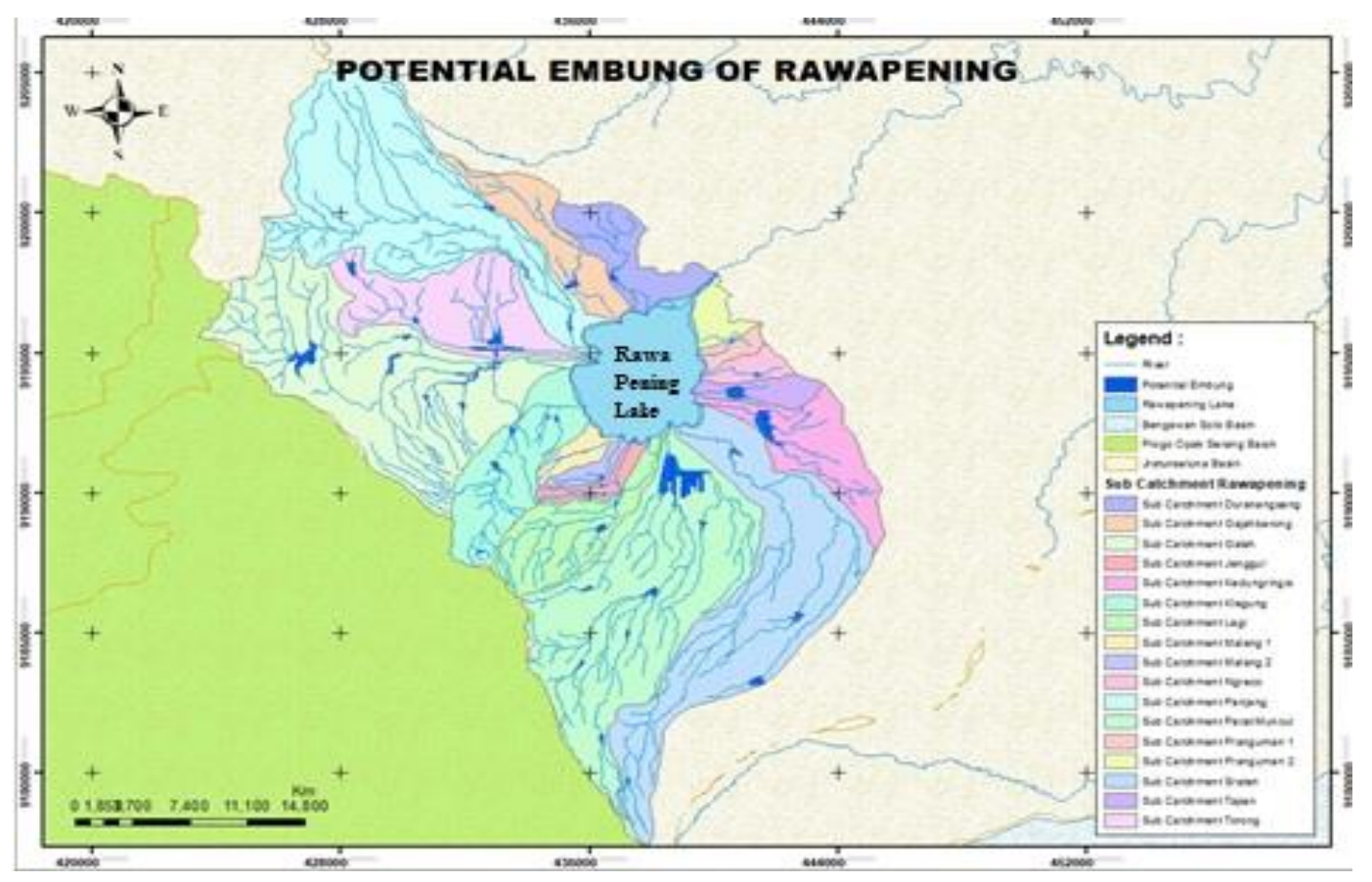

Fig. 2. Location of potential small dam in the Lake of Rawa Pening Watershed (Darsono et al., 2018)

Based on the description above, the construction of small-dams in the Rawa Pening catchment area can be used as a water discharge controller to reduce flooding in the rainy season and regulate water supply in the dry season. The small dams built in the Rawa Pening catchment area in addition to holding water while also receiving and depositing a part of sediment which carried by the stream.

So that the root causes of the high sedimentation rate of the Lake Rawa Pening will overcome and the concept of a lake Rawa Pening as world tourism will realize. Therefore, it is necessary to determine the effect of small dams in the Rawa Pening catchment area on sedimentation rates of Lake Rawa Pening.

\section{Method}

This study aims to analyze the erosion and the rate of sedimentation in Rawa Pening Lake in condition with small-dams and without small-dams. This research is part of the main research in preparing the management plan of Lake Rawa Pening to become an ecotourism-based world tourism. The previous research phase was about potential small dams. Sedimentation is calculated based on soil erosion in the catchment area which is calculated using the USLE formula. Not all materials resulting from soil erosion will be transported and arrive at the outlet of the watershed. The amount of erosion material transported to the watershed outlet (Yield sediment) will obtain from the 
magnitude of the material resulting from the erosion multiplied by the sediment delivery ratio. In the reservoir, this material will undergo a process where some part of the sediment will settle, and some will go carried by the stream to downstream. The stages of the research illustrated in the flowchart of Figure 3.

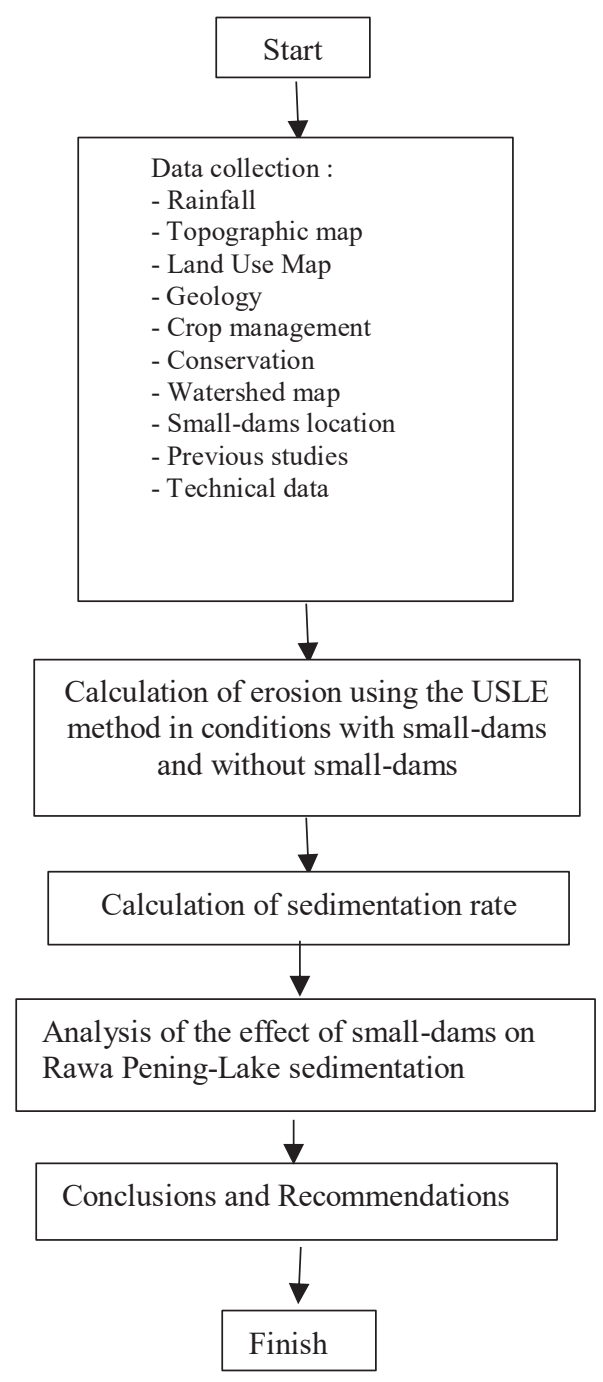

Fig.3. Flowchart of research

\section{Result and discussion}

Based on the results of calculations in Table 1, the erosion rate in each sub-watershed ranges from 0.004 to 35.93 tons/ha/year. The erosion rate that occured in the Klegung and Legi sub-watersheds exceeds the maximum erosion limit of 10 tons/ha/year [5]. In both sub-watersheds, the topography has a steep slope so that the erosion energy produced is also high resulting in high erosion rates. The Klegung sub-watershed is the first supplier of sediment yield to Lake Rawa Pening, and the second supplier is the Legi watershed (Table 2). The total yield of sediment in Lake Rawa Pening under conditions without a small dam is $33,820.47 \mathrm{~m}^{3} /$ year.

In conditions with small-dams, the Legi sub-watershed is the first supplier of sediment yield to Lake Rawa Pening and the second supplier is the Klegung sub-watershed (Table 3).

In Figure 4, the decrease in sediment yield in the Klegung sub-watershed and the Legi sub-watershed are quite high in condition with small-dams. The total sediment yield of Lake Rawa Pening under conditions with small-dams is $7,469.98 \mathrm{~m}^{3} /$ year, and the sediment yield decreases by $77.91 \%$. If small dams will build in the Klegung sub-watershed and the Legi sub-watershed, the total sediment yield of Lake Rawa Pening is $11,139.39$ $\mathrm{m}^{3} /$ year, and the sediment yield decreases by $67 \%$.

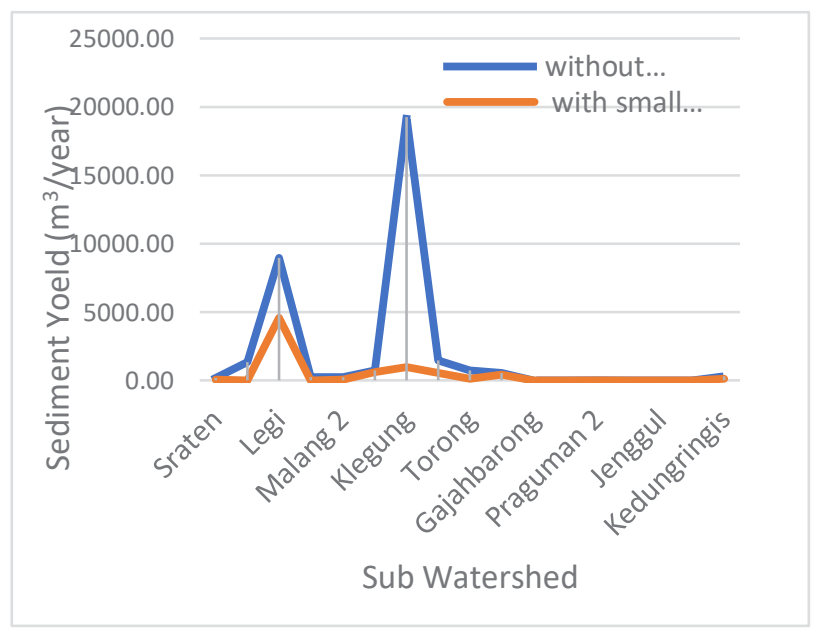

Fig.4. Sediment yield for each sub watershed in conditions without small-dams and with small-dams

Table 1. Erosion in each sub-watershed of Lake Rawa Pening in condition without small-dams

\begin{tabular}{|c|c|c|c|c|c|c|c|c|}
\hline No. & Sub Watershed & Area (Ha) & K (Ton/KJ) & $\mathbf{L S}$ & C & $\mathbf{P}$ & R (KJ/Ha/Year) & Ea (Ton/Ha/Year) \\
\hline 1 & Sraten & $3,984.0$ & 0.32 & 0.56 & 0.008 & 0.06 & $2,079.75$ & 0.168 \\
\hline 2 & Parat & $4,413.0$ & 0.32 & 3.05 & 0.003 & 0.22 & $2,170.90$ & 1.363 \\
\hline 3 & Legi & $1,149.0$ & 0.38 & 1.31 & 0.030 & 0.64 & $2,108.55$ & 20.352 \\
\hline 4 & Ngreco & 243.0 & 0.35 & 0.31 & 0.032 & 0.35 & $1,775.74$ & 2.178 \\
\hline 5 & Malang 2 & 175.0 & 0.44 & 0.34 & 0.032 & 0.28 & $1,765.82$ & 2.394 \\
\hline 6 & Malang 1 & 225.0 & 0.40 & 0.37 & 0.033 & 0.73 & $2,174.24$ & 7.817 \\
\hline 7 & Klegung & $1,461.0$ & 0.42 & 1.64 & 0.054 & 0.51 & $1,887.16$ & 35.930 \\
\hline 8 & Galeh & $3,359.0$ & 0.32 & 0.33 & 0.013 & 0.66 & $1,779.79$ & 1.642 \\
\hline 9 & Torong & $1,769.0$ & 0.42 & 0.30 & 0.008 & 0.68 & $1,772.97$ & 1.256 \\
\hline 10 & Panjang & $4,354.0$ & 0.33 & 0.59 & 0.012 & 0.12 & $1,802.96$ & 0.497 \\
\hline 11 & Gajahbarong & 908.0 & 0.35 & 0.14 & 0.010 & 0.02 & $1,786.83$ & 0.018 \\
\hline 12 & Duranangsang & 814.5 & 0.37 & 0.17 & 0.002 & 0.02 & $1,765.82$ & 0.005 \\
\hline
\end{tabular}




\begin{tabular}{|r|l|r|r|r|r|r|r|r|}
\hline No. & Sub Watershed & Area (Ha) & K (Ton/KJ) & \multicolumn{1}{l|}{ LS } & \multicolumn{1}{|l|}{ C } & P & R (KJ/Ha/Year) & Ea (Ton/Ha/Year) \\
\hline 13 & Praguman 2 & 85.0 & 0.31 & 0.19 & 0.002 & 0.02 & $1,765.82$ & 0.005 \\
\hline 14 & Praguman 1 & 221.0 & 0.31 & 0.19 & 0.002 & 0.33 & $1,765.82$ & 0.076 \\
\hline 15 & Jenggul & 226.0 & 0.31 & 0.15 & 0.002 & 0.02 & $1,765.82$ & 0.004 \\
\hline 16 & Tapen & 326.0 & 0.31 & 0.15 & 0.009 & 0.02 & $1,765.82$ & 0.015 \\
\hline 17 & Kedungringis & $1,329.0$ & 0.31 & 0.13 & 0.011 & 0.76 & $1,827.84$ & 0.611 \\
\hline
\end{tabular}

Table 2. Sediment yield of Rawa Pening Lake in condition without small-dams

\begin{tabular}{|c|c|c|c|c|}
\hline No. & Sub Watershed & Ea $\left(\mathrm{m}^{3} /\right.$ Year $)$ & Sediment Delivery Ratio & Sediment Yield $\left(\mathrm{m}^{3} /\right.$ year $)$ \\
\hline 1 & Sraten & 557.27 & 0.29 & 161.61 \\
\hline 2 & Parat & $5,011.08$ & 0.26 & $1,302.88$ \\
\hline 3 & Legi & $19,486.71$ & 0.46 & $8,963.89$ \\
\hline 4 & Ngreco & 441.03 & 0.51 & 222.72 \\
\hline 5 & Malang 2 & $1,465.69$ & 0.59 & 206.00 \\
\hline 6 & Malang 1 & $43,744.74$ & 0.51 & 747.50 \\
\hline 7 & Klegung & $4,595.53$ & 0.44 & $19,247.68$ \\
\hline 8 & Galeh & $1,851.31$ & 0.31 & 703.50 \\
\hline 9 & Torong & $1,803.67$ & 0.38 & 532.08 \\
\hline 10 & Panjang & 13.78 & 0.30 & 5.92 \\
\hline 11 & Gajahbarong & 3.60 & 0.43 & 1.47 \\
\hline 12 & Duranangsang & 0.33 & 0.41 & 0.19 \\
\hline 13 & Praguman 2 & 13.98 & 0.58 & 6.99 \\
\hline 14 & Praguman 1 & 0.69 & 0.50 & 0.35 \\
\hline 15 & Jenggul & 4.16 & 0.51 & 2.08 \\
\hline 16 & Tapen & 676.70 & 0.50 & 290.98 \\
\hline 17 & Kedungringis & Total sediment Yield of Rawa Pening Lake & $\mathbf{3 3 , 8 2 0 . 4 7}$ \\
\hline & \multicolumn{2}{|l}{ Table 3.43} & \\
\hline
\end{tabular}

Table 3. Sediment yield of Rawa Pening Lake in condition with small-dams

\begin{tabular}{|c|c|c|c|c|c|}
\hline No. & Sub Watershed & $\begin{array}{c}\text { Sub sub- } \\
\text { Watershed }\end{array}$ & $\begin{array}{c}\text { Ea total } \\
\left(\mathrm{m}^{3} / \text { Year }\right)\end{array}$ & Sediment Delivery Ratio & $\begin{array}{c}\text { Sediment Yield } \\
\left(\mathrm{m}^{3} / \text { year }\right)\end{array}$ \\
\hline 1 & \multirow{5}{*}{ Sraten } & Batur & 294.73 & 0.58 & 170.95 \\
\hline 2 & & Taju & 8.91 & 0.56 & 4.99 \\
\hline 3 & & Kumpul Rejo & 16.28 & 0.52 & 8.47 \\
\hline 4 & & Candi Rejo & 158.49 & 0.25 & 39.62 \\
\hline 5 & & Sraten Hilir & 58.45 & 0.53 & 31.15 \\
\hline 6 & \multirow{8}{*}{ Parat } & Kopeng 2 & 27.46 & 0.56 & 15.38 \\
\hline 7 & & Wates & 8.96 & 0.53 & 4.75 \\
\hline 8 & & Kopeng 1 & 0.90 & 0.50 & 0.45 \\
\hline 9 & & Manggihan & 120.37 & 0.47 & 56.57 \\
\hline 10 & & Kalibeji & 25.18 & 0.50 & 12.59 \\
\hline 11 & & Nogosaren & $1,794.84$ & 0.60 & $1,076.90$ \\
\hline 12 & & Rowosari & 120.05 & 0.46 & 55.22 \\
\hline 13 & & Parat Hilir & 8.85 & 0.56 & 4.95 \\
\hline 14 & \multirow{3}{*}{ Legi } & Sepakung & $5,130.25$ & 0.57 & $2,924.25$ \\
\hline 15 & & Kebumen & $16,040.84$ & 0.54 & $8,662.05$ \\
\hline 16 & & Legi Hilir & $8,620.87$ & 0.53 & $4,569.06$ \\
\hline 17 & \multirow{3}{*}{ Ngreco } & Tegaron 1 & 231.22 & 0.58 & 134.11 \\
\hline 18 & & Tegaron 2 & 264.00 & 0.58 & 153.65 \\
\hline 19 & & Ngreco Hilir & 36.89 & 0.56 & 20.59 \\
\hline 20 & \multirow{2}{*}{ Malang 2} & Tegaron 3 & 337.53 & 0.60 & 202.52 \\
\hline 21 & & Malang 2 hilir & 78.93 & 0.57 & 44.68 \\
\hline 22 & \multirow{2}{*}{ Malang 1} & Banyubiru & 564.82 & 0.58 & 327.59 \\
\hline 23 & & Malang 1 Hilir & $1,081.05$ & 0.56 & 603.22 \\
\hline 24 & \multirow{6}{*}{ Klegung } & Kalimalang & $1,652.20$ & 0.61 & $1,007.84$ \\
\hline 25 & & Kebondowo 1 & $26,055.70$ & 0.50 & $12,897.57$ \\
\hline 26 & & Kebondowo 2 & $14,861.98$ & 0.56 & $8,367.29$ \\
\hline 27 & & Wirogomo 2 & $2,248.64$ & 0.57 & $1,283.97$ \\
\hline 28 & & Wirogomo 1 & $1,533.16$ & 0.57 & 866.24 \\
\hline 29 & & Klegung Hilir & $1,845.36$ & 0.52 & 961.43 \\
\hline
\end{tabular}




\begin{tabular}{|c|c|c|c|c|c|}
\hline No. & Sub Watershed & $\begin{array}{c}\text { Sub sub- } \\
\text { Watershed }\end{array}$ & $\begin{array}{c}\text { Ea total } \\
\left(\mathrm{m}^{3} / \text { Year }\right)\end{array}$ & Sediment Delivery Ratio & $\begin{array}{c}\text { Sediment Yield } \\
\left(\mathrm{m}^{3} / \text { year }\right)\end{array}$ \\
\hline 30 & \multirow{6}{*}{ Galeh } & Ngrapah & 116.00 & 0.57 & 66.35 \\
\hline 31 & & Lopait & 945.85 & 0.52 & 489.01 \\
\hline 32 & & Banyukuning & $3,113.91$ & 0.51 & $1,594.32$ \\
\hline 33 & & Delik & 141.85 & 0.52 & 74.33 \\
\hline 34 & & Jambu & 272.36 & 0.58 & 157.42 \\
\hline 35 & & Pojoksari & 561.60 & 0.56 & 316.18 \\
\hline 36 & \multirow{4}{*}{ Torong } & Brongkol 2 & 52.05 & 0.57 & 29.77 \\
\hline 37 & & Brongkol 1 & 357.66 & 0.50 & 178.83 \\
\hline 38 & & Baran & $1,515.69$ & 0.51 & 773.00 \\
\hline 39 & & Torong Hilir & 245.28 & 0.56 & 137.36 \\
\hline 40 & \multirow{4}{*}{ Panjang } & Lodoyong & 44.08 & 0.49 & 21.60 \\
\hline 41 & & Kranggan & $1,805.78$ & 0.48 & 866.77 \\
\hline 42 & & Tambakboyo & 204.80 & 0.25 & 51.20 \\
\hline 43 & & Panjang Hilir & 746.46 & 0.58 & 432.94 \\
\hline 44 & \multirow{2}{*}{ Gajah Barong } & Kupang & 8.76 & 0.49 & 4.32 \\
\hline 45 & & Gajah Barong hilir & 6.72 & 0.50 & 3.37 \\
\hline 46 & \multirow{2}{*}{ Duranangsang } & Rejosari & 1.58 & 0.50 & 0.79 \\
\hline 47 & & Duranangsang Hilir & 2.42 & 0.52 & 1.26 \\
\hline 48 & Praguman 2 & Praguman 2 & 0.33 & 0.58 & 0.19 \\
\hline 49 & \multirow{2}{*}{ Praguman 1} & Ngrapah 2 & 9.51 & 0.60 & 5.70 \\
\hline 50 & & Praguman 1 Hilir & 3.75 & 0.58 & 2.17 \\
\hline 51 & \multirow{2}{*}{ Jenggul } & Kesongo & 0.29 & 0.69 & 0.20 \\
\hline 52 & & Jenggul Hilir & 0.41 & 0.56 & 0.23 \\
\hline 53 & \multirow{2}{*}{ Tapen } & Pramuka & 3.39 & 0.50 & 1.70 \\
\hline 54 & & Tapen Hilir & 0.87 & 0.57 & 0.49 \\
\hline 55 & \multirow{2}{*}{ Kedungringis } & Kebondowo 3 & 950.52 & 0.47 & 446.75 \\
\hline 56 & & Kedungringis Hilir & 178.76 & 0.53 & 95.28 \\
\hline \multicolumn{5}{|c|}{ Total sediment Yield of Rawa Pening Lake } & $7,469.98$ \\
\hline
\end{tabular}

\section{Conclusion}

There are 40 small-dams in 16 tributaries that enter Lake Rawa Pening which affect the rate of sedimentation in Lake Rawa Pening. With these 40 small-dams, the amount of sedimentation decreased to $77.91 \%$. The decrease in sediment yields in Lake Rawa Pening is due to the decrease in sediment yields in the two sub-watersheds that have high erosion levels, namely the Klegung and Legi sub-watersheds. If the reservoir (7 small-dams) will build in the Klegung and the Legi sub-watershed, the decrease in sediment yield is $67 \%$.

The authors are grateful to UNDIP, who funded this research through the Penelitian Strategis scheme in 2018. Thanks are also offered to Balai Besar Wilayah Sungai Pemali Juana, who provided the data used in this study.

\section{References}

1. S. Darsono, S. Suripin, H. Budieny, R.C. Afifah, R. Pujiastuti, F. Soripada, M.I. Hutagalung, L.A. Pamungkas, G.W. Saputra, Benefits of embungs in the Rawa Pening catchment area For Reducing tuntang river flood discharge, Proceedings of the $3^{\text {rd }}$ ICENIS 2018, Semarang, Indonesia (2018)

2. Sulastri, C. Henny, dan U. Handoko, 2016, Kondisi Lingkungan dan Status Trofik Danau Rawa Pening di Jawa Tengah, Oseanologi dan Limnologi di Indonesia, 1(3): 23-38 (2016)
3. D. Apriliyana, Pengaruh Perubahan Penggunaan Lahan Sub DAS Rawapening terhadap Erosi dan Sedimentasi Danau Rawapening, Jurnal Pembangunan Wilayah \& Kota, 11 (1): 103-116 (2015)

4. Tempo. co, Direstorasi, Danau Rawa Pening Kini Lebih Bening, download 12 March 2018

5. Suripin, Pelestarian Sumberdaya Tanah dan Air, Andi Offset, Yogyakarta (2001) 